\title{
DEL PRIORE, Mary (Org.). História das mulheres no Brasil. Coordenação de textos de Carla Bassanesi. São Paulo: Contexto, 1997. 678 p.
}

\author{
Flavia Motta de Mattos* \\ Universidade Federal do Rio Grande do Sul - Brasil
}

História, histórias: multiplicando olhares

\begin{abstract}
A proposta de multiplicar os olhares pelo território da história, buscando também as mulheres, participantes como os homens nos acontecimentos políticos sociais e econômicos, permite incorporar uns e outros como agentes da história, em relação.

Maria Noemi Castilhos Brito, Memória e gênero.
\end{abstract}

Este História das mulheres no Brasil vem coroar uma longa empreitada de historiadoras (e historiadores eventualmente) tributária do movimento feminista, que desde os anos 70 vêm procurando dar visibilidade à mulher, ignorada pela historiografia tradicional. Todos os adjetivos que costumam acompanhar lançamentos editoriais cabem aqui: esta é uma obra obrigatória, importante, instigante e também fascinante. A seleção de textos abarca o período histórico desde os primórdios da colonização até os recentes movimentos sociais em que as mulheres brasileiras estiveram envolvidas. Somados os esforços dos pesquisadores, essa obra resulta de um colossal trabalho de levantamento de fontes primárias, escritas, iconográficas, orais bem como de extensa bibliografia científica, que, se considerada, multiplica senão a autoria ao menos o número dos envolvidos no esforço intelectual de escrita dessa história. Além das fontes e dos períodos históricos variados, os artigos voltam-se para mulheres de diferentes classes sociais em diversas regiões e situações de vida: do meio rural ao urbano, da freira à prostituta, ricas ou professoras, pobres ou analfabetas.

\footnotetext{
* Doutoranda em Antropologia Social.
} 
Num total de vinte autores de diversas origens e numa tal diversidade de temáticas não é de surpreender uma correspondente diversidade de corpus teóricos embasando os vários artigos. Alguns autores parecem contentar-se com aquele objetivo inicial da história das mulheres, ou seja, dar visibilidade às mesmas, denunciando a dominação, sem atentar para diferenças de classe ou étnicas nem para o aspecto multifacetado da dominação. Um ou outro autor (isso mesmo, no masculino) chega a enveredar (1) por uma espécie de feminismo pré-foucaultiano onde a mulher do passado é vista como a reprimida (endossando, portanto, a hipótese repressiva desconstruída por Foucault), mas cuja sexualidade irrompe sob todas as amarras pois a "carne é fraca”. Ou ainda: (2) escorregam por uma outra espécie de feminismo desusado em que autores se aproximam de uma concepção de mulher quase nas linhas de um “eterno feminino” a-histórico - onde as mulheres são vistas homogeneizadas numa “cultura feminina”, onde negras, mestiças, brancas e índias vivem uma harmônica solidariedade, desprezando-se diferenças sociais e de poder entre elas.

Enfim, certas das análises levantam suspeitas de anacronismo/ etnocentrismo. Em um dos textos, por exemplo, a profusão de diminutivos (filhinho, fraldinha, roupinhas, pequerruchos) associada às crianças denota a concepção contemporânea (quiçá maternal) do autor. Esse, não admitindo a ausência de sentimento materno na prática de abandono de crianças, afirma que, se mulheres o fizeram, foi por afeto, para proteger a criança, mesmo quando reconhece adiante que a maioria das crianças abandonadas ("civilizadamente”) na roda dos expostos morria logo depois. Nessa perspectiva, mesmo uma estratégia "bem-sucedida” quanto ao cuidado e criação de crianças, cunhada na literatura antropológica como circulação de crianças, é vista como "uma manifestação bárbara da cultura da pobreza”.

Outros artigos entretanto incorporam discussões mais recentes do próprio feminismo, trabalhando com o conceito de gênero, embora nem sempre numa perspectiva relacional onde o homem é também visível. (É muito difícil fazer uma história das mulheres sem incorrer nos vícios dos "estudos sobre a mulher”.) O livro se ressente de uma discussão teórica mais explícita. O leitor tem que fazê-la, através das entrelinhas, quase como o historiador o faz para ler a presença feminina na documentação. Os melhores artigos são aqueles que aliados à riqueza documental, denotam esse amadurecimento teórico em que se vêem incorporadas as discussões contemporâneas acadêmicas e feministas. 
Considerada a autoria desta resenha (uma historiadora / antropóloga) e o provável leitor da mesma (esta trata-se de uma revista antropológica), talvez não seja tendencioso demais acrescentar que estes bons artigos são justamente aqueles que resgatam a alteridade, a diversidade, demarcam a perspectiva cultural da construção do feminino e o aspecto relacional dessa construção. Vão nessa linha, enfatizando, ora um ora outro aspecto, os excelentes artigos de Luciano Figueiredo ("Mulheres nas Minas Gerais"), Joana Pedro ("Mulheres do Sul”), Magali Engel ("Psiquiatria e feminilidade”) e Cláudia Fonseca (“Ser mulher, pobre e mãe”). Também merecem destaque os trabalhos de Margareth Rago ("Trabalho feminino e sexualidade”), Raquel Soihet ("Mulheres pobres e violência no Brasil”), Mary Del Priore ("Magia e medicina na Colônia”).

Encantador é o texto de Lygia Fagundes Telles (“Mulher, mulheres”), que, na sua sensibilidade de artista/mulher/escritora consegue coadunar o, para nós intelectuais/cientistas, tão difícil paradoxo do nosso universalismo versus diversidade. Mulher, mulheres: talvez esse seja o mesmo paradoxo de se pensar uma história das mulheres numa multiplicidade de histórias de mulheres. História, histórias: esse livro representa uma grande contribuição numa já antiga proposta de multiplicação de olhares. 